\title{
Typology for modular products
}

\author{
Régis Kovacs Scalice \\ Santa Catarina State University \\ e-mail: rks@joinville.udesc.br
}

\begin{abstract}
Typologies are noticeably important tools for the understanding of a particular subject, not only on account of its wide ranging scope, which enables assessing a subject from different aspects, but also because of its standardization, which allows future comparisons with other similar situations. Regarding modular products, the lack of classification was evidenced; hence, enabling to assess different scenarios in product modularization from a wide range of perspectives. In order to bypass this problem, a typology proposal was developed to classify modular products, including the analysis of such a product group from the perspective of six different but complementary factors: modularization objective, modular architecture, modularization strategy, sharing, degree of innovation, and complexity of the obtained system. An example of how to use this typology is presented.
\end{abstract}

Keywords: typology, modular products, classification.

\section{Introduction}

The use of modular products in the industry has many competitive advantages in terms of product variety and component standardization, enabling to service different market segments, however without extensively broadening the quantities of items to be managed during the manufacture of these products.

Despite a decade of considerable research progress on modular product design, particularly regarding the development of product platforms through the modular product family design, there is still no final consensus in terms of nomenclature and definitions. Regarding the classification for product modules, there is a higher maturity level, with the work of Pahl and Beitz (1996) as a reference of great importance in this context.

With regards to modular products as a whole, there is still a wide gap between the state of current knowledge and the existence of nomenclature conformity for classifying this product category. Some typologies described in this work, as that proposed by Ulrich (1995) to categorize the modular architectures by the form of obtaining the final products by a combination of modules, are widespread and widely accepted. For other aspects, as the definition of modular product families and product platform, there is still some confusion with regards to the concepts.

This article presents a typology proposal for the classification of modular products that, hypothetically, allows characterizing each modular product developed under different focal points, differentiating them from each other regarding their nature and purposes. This typology will enable product developers to identify the type of modular design developed and thereby envision new development opportunities.

\section{Bibliographic revision}

According to Bailey (1994), classification is considered as the process of grouping entities by similarity. For Bailey, the term typology is used in a special case called multidimensional classification, where categories (e.g., the types) are differentiated by a perspective that is more conceptual than empirical.

Some typologies can be found in the literature. Garcia and Calonte (2002) suggested a method for classifying innovations so that practitioners and academics can talk with a common understanding of how a specific innovation type is identified and how the innovation process may be unique for that particular innovation type. The authors considered on this proposal both marketing and technological perspective as well as a macro-level and micro-level perspective when identifying innovations. Three possible levels are introduced: radical innovation, really new innovation and incremental innovation.

Another example applied to the innovation area is presented in Trueman (1998), which developed a hierarchical typology called VIPP that helps identifying strategic innovation focuses in companies. This typology is used in 4 dimensions, starting from the value, through the image, the process, until reaching the production level.

Rozenfeld and Amaral (1999) presented a typology proposal for the construction of reference models for the product development process (PDP). This typology presents 
eleven dimensions, in addition to nine sub-dimensions, which enable organizing the PDP according to different values (types). Table 1 presents the typology proposed by the authors.

With respect to modular design, Pahl and Beitz (1996) presented a classification of modules based on their performance function in the system under study. In this case the modules are initially classified as constructive or functional modules. The functional modules are closely linked to the functions performed by the products, while the constructive modules are developed only considering the products' production problems.

The authors also divide the functional modules into subtypes, enabling to classify them as: basic modules, connected to the essential functions of the system; auxiliary modules, which perform auxiliary functions to the basic functions; special modules, which perform functions that are not performed in all the product variants; adaptive modules, necessary to adapt to other systems or outlined conditions; and non-modules, associated to the consumer's specific functions and that should be designed individually.

Besides the function classification, Pahl and Beitz (1996) also mention other categories, based on importance (essential or possible modules), complexity (large modules for assembly, and small ones for components), type of combination (only similar, similar with different modules or non-modules), "resolution" (the capacity to be broken into smaller parts, classified by the number of parts in the module and the number of units and their possible combinations), level of achievement (only modules in software/paper, mixed hardware and software, and only hardware), and the application of modules (closed system with combinatorial planning, or open system with a variety plan).

Another way to classify modules regards its purpose. In this context the work of Erixon et al. (1996) and Zettl et al. (2006) are important references, since the authors make use of modularization guidelines related to the reasons why a product should be modularized. Thus, each module of a specific product will have a specific purpose within the system, for instance, to facilitate recycling or maintenance of the product.

Wie et al. (2003) classified modules simply as functional or physical. In this context a functional module is a grouping of functions, while a physical module is a set of components in a stable and independent assembly.

These classifications could be easily grouped in to a modules typology, as presented on Table 2 .

Concerning classifications applied specifically to modular products, there are several classifications broaching the issue by means of different perspectives, such as the purpose of the product's modularization, how the modular architecture was obtained, the degree of modularity obtained, among others.

Ulrich and Eppinger (2003) address the issue of product architecture from the perspective of the organization purpose when deciding on a modular architecture. Among the factors mentioned, some may be considered more attractive or viable, such as the purpose for modularizing a product,

Table 1. Dimensions of the product development processes typology (ROZENFELD; AMARAL, 1999).

\begin{tabular}{|c|c|c|c|}
\hline Level & \multicolumn{2}{|l|}{ Dimensions } & Values \\
\hline \multirow[t]{4}{*}{ Market } & \multicolumn{2}{|l|}{ Sector } & $\begin{array}{l}\text { Automotive, aviation, petro-chemical, machinery, appliances, white goods, base } \\
\text { industry }\end{array}$ \\
\hline & \multicolumn{2}{|l|}{ Competition } & Monopoly, oligopoly competitive, differentiated oligopoly, perfect competition \\
\hline & \multirow[t]{2}{*}{ Target } & Geographical & local, regional, global \\
\hline & & $\begin{array}{l}\text { Position in the } \\
\text { production chain }\end{array}$ & contact with the end client, middleman in the supply chain \\
\hline \multirow[t]{3}{*}{ Corporation } & \multicolumn{2}{|l|}{ Insertion } & independent unit, Head office, affiliate \\
\hline & \multirow{2}{*}{$\begin{array}{l}\text { Interaction } \\
\text { with units }\end{array}$} & Responsibility & development coordinator, co-development participant \\
\hline & & Team & local, regional, global \\
\hline \multirow[t]{8}{*}{ Company } & \multicolumn{2}{|c|}{ Technical responsibility } & $\begin{array}{l}\text { center for technological adaptation, technology acquisition and adaptation, } \\
\text { product development center, technological development center for manufacturing, } \\
\text { manufacturing center }\end{array}$ \\
\hline & \multirow[t]{2}{*}{ Strategy } & Competitive & cost, quality, time, mixed \\
\hline & & Inter-projects & new, simultaneous, sequential, subsequent \\
\hline & \multicolumn{2}{|c|}{ Initial information } & $\begin{array}{l}\text { idea, performance requirements, part of the product design, part of the product } \\
\text { design and prototypes, product under production }\end{array}$ \\
\hline & \multirow{3}{*}{$\begin{array}{l}\text { Product } \\
\text { complexity }\end{array}$} & Technology "core" & mechanical, electrical, electronics, mechatronics, opto-electronics, chemical \\
\hline & & Internal & number of components, number of software lines, number of inputs and stages \\
\hline & & Interface with user & high complexity, low complexity \\
\hline & \multicolumn{2}{|c|}{ Innovation degree } & $\begin{array}{l}\text { advanced research and development, breakthrough or radical, platforms or new } \\
\text { generation and by products }\end{array}$ \\
\hline
\end{tabular}


Table 2. Modules typology.

\begin{tabular}{|c|c|c|}
\hline Factor & & Types \\
\hline \multirow[t]{6}{*}{ Function } & \multicolumn{2}{|c|}{ Production modules } \\
\hline & \multirow{5}{*}{$\begin{array}{l}\text { Functional } \\
\text { modules }\end{array}$} & Basic modules \\
\hline & & Auxiliary modules \\
\hline & & Special modules \\
\hline & & Adaptive modules \\
\hline & & Non-module \\
\hline \multirow[t]{2}{*}{ Complexity } & \multicolumn{2}{|l|}{ Large modules } \\
\hline & \multicolumn{2}{|l|}{ Small modules } \\
\hline \multirow[t]{2}{*}{ Importance } & \multicolumn{2}{|c|}{ Essential modules } \\
\hline & \multicolumn{2}{|c|}{ Possible modules } \\
\hline \multirow[t]{2}{*}{ Stage of development } & \multicolumn{2}{|c|}{ Functional modules } \\
\hline & \multicolumn{2}{|c|}{ Physical modules } \\
\hline \multirow[t]{12}{*}{ Objective } & \multirow{3}{*}{$\begin{array}{l}\text { Development } \\
\text { and design }\end{array}$} & Carry-over \\
\hline & & Technology push \\
\hline & & Product plan \\
\hline & \multirow[t]{2}{*}{ Variance } & Technical specification \\
\hline & & Styling \\
\hline & \multirow[t]{2}{*}{ Manufacturing } & Common unit \\
\hline & & Process / organization \\
\hline & Quality & Separate test \\
\hline & Purchase & Black-box engineering \\
\hline & \multirow[t]{3}{*}{ After sales } & Service and maintenance \\
\hline & & Upgrading \\
\hline & & Recycling \\
\hline
\end{tabular}

including: making product modifications easier (updates, optional additions, replacing parts that wear out, replacing consumables, flexibility to use and easier reuse), variety of products (quantity of products produced by the company in a specified period of time) and standardization of components (using the same parts in different products). Concerning the objective "facilitate product modifications", Ulrich (1995) supplements the category by stating that changes to the product may occur during the product's life cycle or through the product's different generations.

Dahmus et al. (2001) also describe objectives that determine the partition of the product into modules with a view similar to that of Ulrich and Eppinger (2003). However, the authors include concerns about the optimization of the product's life cycle through design techniques for X (DFx) as one of the company goals to use the modular design.

In terms of the defined architecture for the modular product, Ulrich (1995) presented one of the most widespread and accepted classifications among researchers in this area. The authors describe three distinct types of modular architectures:

- Slot: the interfaces of each component are of different types, allowing only some of them to be exchanged (e.g., car audio systems).
- Bus: in this case there is a common bus where different components of the same interfaces can be coupled (e.g., computer mainboards).

- Sectional: all of the interfaces are of the same type, with no single base component for others to fit (e.g., some types of pipes and modular furniture).

Otto and Wood (2001) used the classification of architectures proposed by Ulrich (1995), adding an additional type:

- Mix-modular architecture: several standard components are combined through networks of modules rather than simple chaining, as in the case of sectional modular architecture. The modules must be equipped with at least two additional interfaces to create a new device. It should be emphasized that the big difference between sectional modular architecture and mix-modular lies in the interface that is standardized in the first case and not in the second one, which always combines at least two of the three types previously mentioned.

Göpfert apud Zettl et al. (2006) classify products into four categories: modular product, complete product (defined as the opposite of modular), modular-functional product and physical-modular product. However, the first two categories seem to be of a higher level of abstraction, and the other two are specializations of the first category. The author characterizes the modular-type as products containing functions that are independent of each other, but whose product has a strong physical dependence on each other (Swiss army knives). The physical modular products include functions with strong functional dependencies, but poor physical dependencies (wireless telephones). This classification has a strong connection to how the product modules interact among themselves.

Another topic of interest in the literature is the form or strategy of modularization adopted during the development of the modular product. Fixson (2001) describes three possible ways to obtain a modular product. The first category, which the author called systemic perspective, contains the modularization strategies of products in which the elements of the system (components and functions) and their relationships (interfaces) are analyzed together or separately. The second type, the hierarchical perspective, is divided into two strategies, the bottom-up and top-down. In the first case the product is broken into smaller pieces (components or elementary functions) to then are regrouped into modules. In the top-down strategy, the market is studied, segmented into categories and sequences, to then propose architectures to serve these segments. This type of strategy has a strong bond with the consumer, including the need to maximize the use of common parts. Lastly, the author describes the life cycle perspective, in which each field of application (product development, production, use and 
removal of the product from the market) has a different view of the module, as well as specific goals.

Another important aspect for modular products is the development of single architecture and shared architecture products.

Works such as that of Erixon et al. (1996) and Zettl et al. (2006), focused on product modularization based on their life cycle aspects, are examples of methods applicable to the development of a single product in a modular manner, segmenting the functions and components of a specific product into modules using modularization guidelines.

Wie et al. (2003) simply classified modules as either functional or physical. In this context a functional module is a grouping of functions, while a physical module is a set of components in a stable and independent assembly.

A second research line has works associated to modular family designs. It is important to emphasize the possibility of developing families of products differently, such as through size seriated products. However, regardless of the strategy chosen, the development of families enables increasing the variety of products, reducing lead-times and lowering costs.

For Farrell and Simpson (2003), a family of products can be defined as a group of related products that share similar characteristics, components and subsystems, and meet a variety of market niches. Fujita and Ishii (1997) emphasize the fact that the architecture of a single product deals mainly with modularity, while the architecture of product families also includes the search for similarity between product variants.

The design of product families has been increasingly highlighted in the literature, mainly regarding the development of platforms (CHEN; LIU, 2005; SIMPSON, 2003; FARRELL; SIMPSON, 2003). Simpson et al. (2001) state that a family of modular products is a widely known approach to the development of a reconfigurable platform, which is easily modified or updated by the addition, subtraction and replacement of modules.

Despite the similarities of concepts, this work adopts product platforms and modular product families with different but complementary themes. Thus, the design of product families based on modular design could be one of the possible strategies for developing product platforms.
Fujita (2005), underscores that different products can share a single module for different consumer needs, if the functional requirements and economies of scale are maintained. For the author, the common use of some attributes among different modules can contribute to the performance of product variety, since it allows unifying parts, manufacturing processes and other factors.

However, it should be noted that the platform concept is also connected to the degree of innovation of the project that is being developed. Rozenfeld et al. (2006) lists three main design categories regarding innovation: Radical Projects (breakthrough), which involve significant changes and may lead to a new category or family of products; Platform Designs or Next Generation, including the evolution of a family of existing products or the design of a basic structure of the product that is common between the various models that comprise a family of products; and lastly the Incremental or Derivative Designs, which include projects to reduce cost or adding a new product platform.

Another factor that has been frequently broached in the literature is the complexity of modular products, intimately tied to the concept of modularity as a measuring indicator of how modular a product is. This parameter is a measure of how much the product departs from a complete product architecture. In his methodology, Holonic Product Design (HPD), Marshall (1997) presents the possibility to define a desired level for the product modularity. To contribute to this task, the author presents a questionnaire, shown in Table 3, where scores between 17 and 21 correspond to a very high level of modularity, 11 to 16 is a high level, 5 to 10 a medium level and 0 to 4 a low level. Another more complex example of modularity classification can be considered in Hölttä et al. (2005).

These scores alone only allow assessing the modular products according to specific approaches. In order to propose a broader typology for modular products, Strong (2003) proposed the Modularity Type Space (MTS), or space of modular types, which uses three dimensions to categorize modular products: interface (standard or exclusive) and architecture (with or without base) and degree of modularity

In spite of representing an advance, the Strong typology does not address all the factors discussed above,

Table 3. Questionnaire to determine the desired level of modularity (MARSHALL, 1997).

\begin{tabular}{|c|c|c|c|}
\hline What is the correlation? & Strong & Moderate & Neutral \\
\hline To what extent does the user want/require the product to be reconfigurable? & 3 & 1 & 0 \\
\hline What is the degree of possible similarity between the product and another one? & 3 & 1 & 0 \\
\hline To what extent is the product most likely to be modified/updated in the future? & 3 & 1 & 0 \\
\hline How complex is the development of the project and product? & 3 & 1 & 0 \\
\hline To what extent is the product constrained by the manufacturing processes and strategy? & 3 & 1 & 0 \\
\hline To what extent will the product include elements that require maintenance or replacement? & 3 & 1 & 0 \\
\hline What is the possible level of recycled/reused elements in the product? & 3 & 1 & 0 \\
\hline
\end{tabular}


leaving out important dimensions such as the objective of modularization, strategy of modularization and degree of product innovation.

The next topic presents a typology proposal based on the aforementioned review, which uses all the dimensions described above to classify modular products.

\section{Typology of modular products}

The typology in Table 4 was developed based on the literature review described above. The different types of modular products were divided into seven factors that are considered essential to understanding the type of modular product developed. Other factors could be considered for evaluating the modular product, such as technical responsibility, initial information and others. However, they do not differ significantly from the existing types of complete architecture products, since they are inherent to the product development process. For a broader view of factors related to the PDP, Rozenfeld and Amaral (1999) is a recommended reading.

Table 4. Typology of modular products.

\begin{tabular}{|c|c|}
\hline Factor & Types \\
\hline $\begin{array}{l}\text { Purpose of } \\
\text { modularization }\end{array}$ & $\begin{array}{l}\text { - Facilitate changes in the Product } \\
\text { - During the product's life cycle } \\
\text { - Through the product's generations } \\
\text { - Increase variety of products } \\
\text { - Standardize products and/or SSCs } \\
\text { - Improve product performance } \\
\text { - Meet the client's special needs } \\
\text { - Optimize (parts of) the product's life cycle } \\
\text { of the }\end{array}$ \\
\hline $\begin{array}{l}\text { Modular } \\
\text { Architecture }\end{array}$ & $\begin{array}{l}\text { - Slot } \\
\text { - Bus } \\
\text { - Seccional } \\
\text { - Mix-modular }\end{array}$ \\
\hline $\begin{array}{l}\text { Interaction } \\
\text { between modules }\end{array}$ & $\begin{array}{l}\text { - Modular-physical product } \\
\text { - Functional physical product } \\
\text { - Hybrid product } \\
\end{array}$ \\
\hline $\begin{array}{l}\text { Modularization } \\
\text { strategy }\end{array}$ & $\begin{array}{l}\text { - Systemic } \\
\text { - Elements } \\
\text { - Relationships } \\
\text { - Elements-relationships } \\
\text { - Hierarchical } \\
\text { - Bottom-up } \\
\text { - Top-down } \\
\text { - Life cycle } \\
\end{array}$ \\
\hline Sharing & $\begin{array}{l}\text { - Single Product } \\
\text { - Family of products }\end{array}$ \\
\hline $\begin{array}{l}\text { Degree of } \\
\text { innovation }\end{array}$ & $\begin{array}{l}\text { - Breakthrough or radical } \\
\text { - Platform of new generation } \\
\text { - By-product }\end{array}$ \\
\hline $\begin{array}{l}\text { Complexity } \\
\text { (modularity) }\end{array}$ & $\begin{array}{l}\text { - High } \\
\text { - Average } \\
\text { - Low }\end{array}$ \\
\hline
\end{tabular}

The first factor chosen is the modularization purpose, defined here as the goal to be achieved by deciding on a modular architecture for the product. This category is particularly far reaching, given that there are many modularization drivers, with the products mentioned by Ulrich and Eppinger (2003) as the objectives to be modularized and the basis used in this proposal. Ulrich's work (1995) was also used complementary.

In addition to the modularization goals already described by these authors, two others were added that are based on specific points of other authors' work. In the first case, "meeting special needs", are included for products that are related to the existence of non-modules (conveying specific user functions) described by Pahl and Beitz (1996), which characterizes the ability to modularize products as a way to facilitate their customization through a modular design.

Another addition is "Optimize (parts of) the product's life cycle", whose inclusion decision is coupled to the guidelines of modularity proposed by Erixon et al. (1996) and Zettl et al. (2006), related to the optimization of the life cycle of the product, and the incorporating view of built techniques DFx (DAHMUS et al., 2001). The modularization guidelines themselves were not included because they are related to the modules. It is also important mentioning that the different types within the objective factor of modularization are not ruled out and there may be modular products with different objectives.

The second factor of the proposed typology is the modular architecture obtained, that is, the forms and the modules organize themselves to obtain the final product. To define these types, the work of Ulrich (1995) was used as reference and to complement the types of modular architecture, Otto and Wood (2001) was used. It is important to emphasize that as it is a typology for modular products, the complete architecture is not considered.

Another factor related to characterizing the architecture is the form of interaction between the modules of the product, a measure of the physical and functional interdependence of the parts (modules) to form the whole (product). The references used for these are the works of Göpfert apud Zettl et al. (2006) and Wie et al. (2003), defining for the proposed typology the types of modular products in this factor:

- Modular Product-physical: essentially composed of physical modules;

- Modular Product-functional: essentially composed of functional modules;

- Modular Product-hybrid: result of the balance between physical and functional modules.

The next factor, modularization strategy, is directly associated to the type of design effort made to obtain the modular system developed. The main reference used for this is Fixson's work (2001), who characterizes the existing 
Table 5. Analysis of modular products for mariculture developed by Scalice et al. (2002).

\begin{tabular}{|c|c|c|}
\hline Factor & Types & Justification \\
\hline Purpose of modularization & $\begin{array}{l}\text { Increase variety of products } \\
\text { Standardize products and/or SSCs }\end{array}$ & $\begin{array}{l}\text { The largest possible number of requirements were sought to be met, while } \\
\text { reducing the total cost of the product family from the product through } \\
\text { the reuse of components. }\end{array}$ \\
\hline Modular architecture & Bus & $\begin{array}{l}\text { There is predominance for the type of bus, the modules M1 are the basis } \\
\text { on which the settings are assembled. }\end{array}$ \\
\hline Interaction between modules & Functional modular- product & Because the modules are, almost entirely, carriers of functions. \\
\hline Modularization strategy & $\begin{array}{l}\text { Hierarchical } \\
\text { Bottom-up }\end{array}$ & $\begin{array}{l}\text { The functional modeling was used as the basis, and the elementary } \\
\text { functions are integrated into the modules. }\end{array}$ \\
\hline Sharing & Family of products & 8 different overall functions were developed. \\
\hline Degree of innovation & Breakthrough or radical & A new family was developed, with no products previously developed. \\
\hline Complexity (modularity) & $\begin{array}{l}\text { High } \\
\text { Average } \\
\text { Low }\end{array}$ & $\begin{array}{l}\text { Average to high. There are several multifunction modules, which } \\
\text { characterizes a stage between the one fully modular and the integral } \\
\text { one. The index obtained through the questionnaire in Table } 4 \text { was } 11 \text {. }\end{array}$ \\
\hline
\end{tabular}

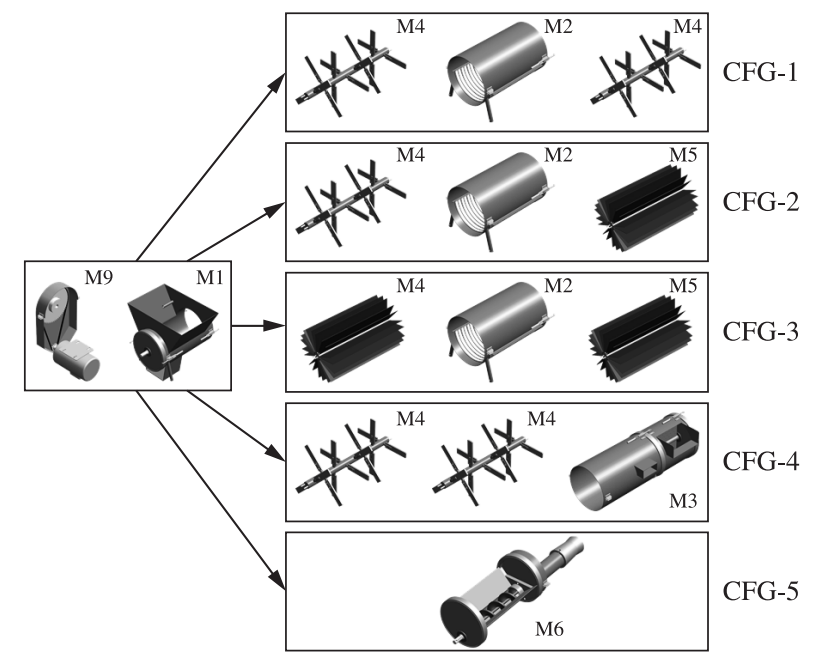

Figure 1. Possible product configuration for Mariculture (SCALICE et al., 2002).

methodologies for the modular design in three major types. Also important, in this case, is that the modular product may have been developed using one or more types of strategy.

Sharing is the most simple in all the factors adopted for the proposed typology. It separates the modular products into two types: a single product or product family. In the case of single products, its structure is not shared between product variants. However, in the case of a family of modular products, the sharing of modules is possible or even essential for the competitiveness of the family in question.

The innovation level of the product, as mentioned before, is associated to the development of products in general, not to a particular feature of modular products. However, adopting this typology enables to differentiate, for instance, a completely new family of products from one that was derived from an existing project. This classification is complementary to the sharing factor, enabling to better specify the type of project developed.
The last factor used is complexity. This typology uses complexity to measure the product's degree of separation, thus a completely integral structure was characterized as not very complex and another one completely modular and defined as highly complex. This measure of complexity of the system is called by various authors as the product's degree of modularity. One of these authors, chosen as a reference for the classification's simplicity, is Marshall (1997).

\section{Classification example}

To illustrate the use of the proposed typology, the modular products designed for mechanizing the mussel farming processes were used as reference, presented by Scalice et al. (2002). The result is shown in Table 5, and the possible module configurations are illustrated in Figure 1.

\section{Final comments}

This paper only demonstrates one typology proposal for the classification of modular products. Its development is in the early stages, still requiring a more thorough validation. Therefore, two fronts of assessment will be conducted; one based on the available literature on the subject, in particular the examples of developed projects, and the second front, a validation by experts. However, the results obtained from the initial applications of this tool, such as the one presented in item 4 of this article, seem to be promising.

\section{References}

BAILEY, K. D. Typologies and taxonomies - an introduction to classification techniques. Sage publications, 1994.

CHEN, K.; LIU, R. Interface strategies in modular product innovation. Technovation, v. 25, p. 771-782, 2005. http://dx.doi.org/10.1016/j.technovation.2004.01.013

DAHMUS, J. B.; GONZALEZ-ZUGASTI, J. P.; OTTO, K. N. Modular Product Architecture. Design Studies, v. 22, 
n. 5, p. 409-424, 2001. http://dx.doi.org/10.1016/S0142694X(01)00004-7

ERIXON, G., YUXKULL, A., ARNSTROM, A. Modularity - the Basis for Product and Factory Reengineering Annals of the CIRP, v. 45, n. 1, p. 1-6, 1996.

FARRELL, R.; SIMPSON, T. W. Product Platform Design to Improve Commonality in Custom Products. Journal of Intelligent Manufacturing, v. 4, p. 541-556, 2003. http://dx.doi.org/10.1023/A:1027306704980

FIXSON, S. K. Three perspectives on modularity - a literature review of a product concept for assembled hardware products. Massachusetts: Massachusetts Institute of Technology Engineering Systems Division, 2001. Available from: <http://esd.mit.edu/WPS/esd-wp-2001-06.pdf>.

FUJITA, K. Product Variety Optimization under Modular Architecture. Computer-Aided Design, v. 34, p. 953-965, 2005. http://dx.doi.org/10.1016/S0010-4485(01)00149-X

FUJITA, K.; ISHII, K. Task Structuring Toward Computational Approaches to Product Variety Design. In: DESIGN AUTOMATION CONFERENCE ASME, 1997, Sacramento. Proceedings... ASME, 1997. Paper n. 97DETC/DAC-3766.

GARCIA, R.; CALANTONE, R. A critical look at technological innovation typology and innovativeness terminology: a literature review. Journal of Product Innovation Management, v. 19, p. 110-132, 2002. http://dx.doi.org/10.1016/S07376782(01)00132-1

GOMES, L. M.; MORAES, J. C.; JARDIM, E. G. M. Mudança na Tecnologia de Gestão da Produção: Caracterizando um caso de sucesso. In: ENCONTRO NACIONAL DE ENGENHARIA DE PRODUÇÃO - ENEGEP, 21., 2001, Salvador. Anais... Salvador: ABEPRO/ UFBa, 2001.

HÖLTTÄ, K.; SUH, E. S.; DE WECK, O. Tradeoff between Modularity and Desempenho for Engineered Systems and Products. In: INTERNATIONAL CONFERENCE ON ENGINEERING DESIG, 2005, Melbourne. Proceedings... Melbourne: Design Society, 2005.

MARSHALL, R. Holonic Product Design. Loughborough: Loughborough University, 1997. Available from: <http://www. iboro.ac.uk.departments/en/research/cae/res_int/ipps/mod2. htm. Access in: mar. 2002.

OTTO, K.; WOOD, K. Product Design: Techniques in Reverse Engineering and New Product Development. Upper Saddle River: Prentice Hall, 2001.

PAHL, G.; BEITZ, W. Engineering design. A systematic Approach. London: Springer-Verlag Limited, 1996.
ROZENFELD, H.; AMARAL, D. C. Proposta de uma tipologia para processos de desenvolvimento de produto visando a construção de modelos de referência. In: CONGRESSO BRASILEIRO DE GESTÃO DO DESENVOLVIMENTO DE PRODUTO, 1., 1999, Belo Horizonte. Anais... Belo Horizonte: NTQI/UFMG, 1999.

ROZENFELD, H. et al. Gestão do Processo de Desenvolvimento de Produtos: uma referência para a melhoria do processo. Ed. Saraiva. 2006.

SCALICE, R. K.; FORCELLINI, F. A.; BACK, N. B. Development of a modular product family for the mechanization of mussel farming and processing in Santa Catarina. Product: Management \& Development, v. 1, n. 3, p. 47-60, 2002. Available from: <http://www.pmd.hostcentral.com.br/>.

SIMPSON, T. W. Product platform design and optimization: Status and promise. Proceedings of the ASME Design Engineering Technical Conference, v. 2A, p. 131-142, 2003.

SIMPSON, T. W.; MAIER, J. R. A.; MISTREE, F. Product Platform Design: method and application. Research in Engineering Design, v. 13, p. 2-22. 2001. http://dx.doi. org/10.1007/s001630100002

STRONG, M. T. Tools And Metrics For Evaluating Modular Product Concepts Based On Strategic Objectives. 2003. $147 \mathrm{f}$. Thesis (Master of Science)-Brigham Young University, Provo, 2003.

TRUEMAN, M. Managing innovation by design - how a new design typology may facilitate the product development process in industrial companies and provide a competitive advantage. European Journal of Innovation Management, v. 1, n. 1, p. 44-56, 1998. http://dx.doi.org/10.1108/14601069810199663

ULRICH, K. The Role of Product Architecture in the Manufacturing Firm. Research Policy, n. 24, p. 419-440, 1995. http://dx.doi. org/10.1016/0048-7333(94)00775-3

UlRICH, K. T.; EPPINGER, S. D. Product Design and Development. McGraw-Hill, 2003.

WIE, M. J. V. et al. Representing Product Architecture. In: ASME DESIGN ENGINEERING TECHNICAL CONFERENCES AND COMPUTERS AND INFORMATION IN ENGINEERING CONFERENCE, 3., 2003, Chicago. Proceedings... ASME, 2003.

ZETTL, M.; SELIGER, G.; BILGEN, E. Product Life Cycle Oriented Methodology Supporting the Development of Modular Product Structures. In: GLOBAL CONFERENCE ON SUSTAINABLE DEVELOPMENT AND LIFE CYCLE ENGINEERING, 4., 2006, São Carlos.. Proceedings... São Carlos: Suprema, 2006. 